\title{
The importance of increasing urology exposure among undergraduates: A U.K. Perspective
}

\section{Michael S. Floyd Jr., MCh FRCS (Urol)}

Specialist Registrar in Urology, Southport and Ormskirk Hospital Town Lane, Kew, Southport, Merseyside, U.K.

Cite as: Can Urol Assoc J 2015;9(11-12):426. http://dx.doi.org/10.5489/cuaj.3361 Published online December 14, 2015

I read with great interest the recent paper by Jones et $\mathrm{al}^{1}$ detailing the attitudes towards urology as a career choice amongst medical students and foundation year trainees in the U.K. The decline in undergraduate exposure to urology is also discussed and the results of an internet-based survey involving six medical schools are presented.

This study excluded graduates from non-U.K. medical schools. The authors should acknowledge that many nonU.K. graduates (of which I am one) elect to train in urology in the U.K. at a postgraduate level due to its history of specialist training, which is internationally recognized. If non-U.K. graduates, at foundation level, had been included in this survey, urology may have been a more popular career option.

According to the results in Figure 1, Jones at al report that urology was the least likely speciality to be chosen by new graduates, as only $7 \%$ would most likely pursue it as a career compared to general surgery at $17 \%$. Interestingly, ophthalmology, another specialty often underrepresented at the undergraduate level, was not offered as a future career choice. Why was this omitted?

It is reassuring to see that male catheterization was assessed as an index technique, but only $21 \%$ of males surveyed either agreed $(17 \%)$ or strongly agreed $(4 \%)$ at being confident at the procedure. This does indicate that junior practitioners receive inadequate training in catheter management, as previous studies have shown that $76 \%$ of newly qualified doctors feel their catheter training was inadequate. ${ }^{2}$

The secondary outcomes reported are commendable. The idea of a designated workshop day was supported by $88 \%$ of respondents. A 2013 study examining out-of-hours calls to urology registrars also supported the idea of a defined urology workshop at the beginning of a core rotation for junior trainees in an effort to reduce unnecessary out-ofhours calls. ${ }^{3}$

\section{CUAJ Letters is an open forum to discuss papers published in CUAJ. Letters are published at the discretion of the editors, and are subject to abridgement and editing for style and content. Letters can be sent to the Editor at journal@cua.org.}

Although $68 \%$ of respondents stated that they felt comfortable making a referral, greater than one-third did not feel confident assessing an acute urology admission. ${ }^{1}$ We again demonstrated that junior trainees (foundation and core level) are the most frequent callers seeking advice, but that the advice relayed is frequently insufficient. ${ }^{3}$ Therefore, it should be acknowledged by the authors of this study that although $68 \%$ of respondents were comfortable making a referral, this is not an objective measurement, as the opinion of the recipient has not been sought, nor the quality of the referral validated.

This work does highlight the decline in exposure to urology at the undergraduate level. This problem is not limited to the U.K., nor is it a new one: in 1994 Benson commented that $15 \%$ of new graduates had never experienced an undergraduate rotation in urology. ${ }^{4}$ Medical education has evolved with simulation-based training and problem-based learning (as opposed to bedside teaching and didactic lectures) and it is unfortunate that newly qualified practitioners may never experience rotations in certain specialties.

The authors state that urology workshops are not routinely incorporated into U.K. undergraduate teaching and recommend their introduction. This is an important point, as designated workshops on catheter management, basic uroradiology, clinical assessment, and result interpretation prior to starting a foundation year may help to make urology more attractive as a postgraduate surgical career.

Competing interests: The author declares no competing financial or personal interests.

\section{References}

1. Jones P, Prasad Rai B, Qazi HAR, et al. Perception, career choice and self -efficacy of U.K. medical students and junior doctors in urology. Can Urol Assoc J 2015;(9-10):E573-8. http://dx.doi.org/10.5489/cuaj.2919

2. Thomas AZ, Giri SK, Meagher D, et al. Avoidable iatrogenic complications of urethral catheterization and inadequate intern training in a tertiary-care teaching hospital. BJU Int 2009;104(8):1109-12. http:// dx.doi.org/10.1111/i.1464-410X.2009.08494.x

3. Floyd Ir MS, Gulur DM, Lyttle M, et al. Is it good to talk? Analyzing the out-of-hours telephone workload of urology registrars in a university teaching hospital. Ann R Coll Surg Engl (Bulletin) 2013;95(3):97-101.

4. Benson GS. The decline of urological education in U.S. medical schools. J Urol 1994;152(1):169-70.

Correspondence: Mr. Michael S. Floyd Jr., Southport and Ormskirk Hospital Town Lane, Kew, Southport, Merseyside, PR 8 6PN, U.K.; michaelfloyd@nhs.net 


\section{Increasing urology exposure among undergraduates: A U.K. Perspective Authors' response}

\section{Patrick Jones, MBChB; Bhavan Prasad Rai, FRCS; Hasan A.R. Oazi, FRCS,; Bhaskar K. Somani, FRCS, Ghulam Nabi, FRCS ${ }^{1}$}

'Department of Urology, Ninewells Hospital, Dundee, U.K.; ${ }^{2}$ Gartnavel General Hospital, Glasgow, U.K.; ${ }^{3}$ University Hospital Southampton NHS Trust, Southampton U.K.

Cite as: Can Urol Assoc J 2015;9(11-12):427. http://dx.doi.org/10.5489/cuaj.3413

Published online December 14, 2015

$\mathrm{T}$ he authors acknowledge the interest and thoughtful reflections shared by Mr. Floyd in response to our recent study. ${ }^{1}$ Given that junior doctors in the U.K. enter a separate training route for ophthalmology, which does not incorporate the core surgical pathway, this specialty was omitted.

The authors fully acknowledge that many doctors undertake urology training in the U.K. after completing their medical degrees abroad. Our study addressed the exposure deficit at the undergraduate level in the U.K., focusing on trainees graduating from U.K. medical schools. We envisage that implementation of a revised undergraduate curriculum, adopted uniformly by U.K. medical schools, may serve to address many of the issues described in our findings.

Urology is a field rich in advances and opportunities and it is, therefore, our obligation to educate and inspire the next generation. As mentioned in our paper, we agree with Mr. Floyd about an evolving need for simulation-based training and workshops augmented with problem-solving and non-technical skills rather than traditional didactic lectures. ${ }^{2}$ Although the value of bedside teaching and assessment cannot be overlooked, this should be in conjunction with simulation and hands-on-training in keeping with modern teaching and training. ${ }^{3}$

Competing interests: The authors declare no competing financial or personal interests.

\section{References}

1. Jones P, Prasad Rai B, Qazi HAR, et al. Perception, career choice and self -efficacy of U.K. medical students and junior doctors in urology. Can Urol Assoc J 2015;(9-10):E573-8. http://dx.doi.org/10.5489/ cuai.2919

2. Rai BP, Stolzenburg JU, Healy S, et al. Preliminary validation of Thiel embalmed cadavers for laparoscopicradical nephrectomy. J Endouro/ 2015;29(5):595-603. http://dx.doi.org/10.1089/end.2014.0719

3. Jones P, Rai BP. The status of bedside teaching in the United Kingdom: The student perspective. Adv Med Educ Pract 2015;6:421-9. http://dx.doi.org/10.2147/AMEP.S83407

Correspondence: Mr. Patrick Jones, Ninewells Hospital and Medical School, University of Dundee, Scotland, UK, DDI 9SY; patrick.jones1@nhs.net 